\title{
The Amount of Propofol Used Should be Specified in Milligrams Instead of Milliliters
}

\section{Kullanılan Propofol Miktarı Mililitre Yerine Miligram Olarak Belirtilmelidir}

\section{(D) Rümeysa Karaçuha Sürücü}

Samsun Training and Research Hospital, Clinic of Anesthesiology and Reanimation, Samsun, Turkey

Dear Editor in Chief,

Esophagogastroduodenoscopy (EGD) is a common diagnostic procedure which requires sedation for most patients $(1,2)$. Propofol is an agent often used alone or in combination in endoscopic procedures such as EGD and/or colonoscopy. The median effective dose (ED50) of propofol for loss of consciousness is 1 to $1.5 \mathrm{mg} / \mathrm{kg}$ after a bolus. The duration of hypnosis is dose dependent and 5 to 10 minutes after $2-2.5 \mathrm{mg} / \mathrm{kg}$ (3).

I read the article entitled "The correlation of pain catastrophizing scale and sedation in patients undergoing gastroscopy” belonging to Duman Aydın et al. in Bagcilar Medical Bulletin 2021;6(1):1-6. In the section of "material and methods" in this study, it was stated that intravenous propofol was administered to patients during EGD at a dose of $1 \mathrm{mg} / \mathrm{kg}$, and doses of $0.3-0.5 \mathrm{mg} / \mathrm{kg}$ were added to patients with pain or movement during the procedure. In the results section, the amount of propofol used for sedation was $80.3 \pm 16.2 \mathrm{~mL}$, both in the text and in the table. Detailed information about propofol dilution is not provided in the article. $1 \%$ propofol contains $10 \mathrm{mg} / \mathrm{mL}$ of active substance. When used in a pure state, the amount of $80.3 \pm 16.2 \mathrm{~mL}$ indicates that $803 \pm 162 \mathrm{mg}$ is used, which will correspond to a very high amount for short-term (average of 5.53 \pm 2.15 minutes in the study) operations. In my opinion, it would be more appropriate to specify the amount of propofol used in sedation in $\mathrm{mg}$ instead of $\mathrm{mL}$ in the article.

Keywords: Esophagogastroduodenoscopy, propofol, sedation Anahtar kelimeler: Özefagogastroduodenoskopi, propofol, sedasyon

\section{Ethics}

Peer-review: Internally peer-reviewed.

Financial Disclosure: The author declared that this study received no financial support.

\section{References}

1. Wu Y, Zhang Y, Hu X, Qian C, Zhou Y, Xie J. A comparison of propofol vs. dexmedetomidine for sedation, haemodynamic control and satisfaction, during esophagogastroduodenoscopy under conscious sedation. J Clin Pharm Ther 2015;40(4):419-425.

2. Patterson KW, Casey PB, Murray JP, O'Boyle CA, Cunningham AJ. Propofol sedation for outpatient upper gastrointestinal endoscopy: comparison with midazolam. Br J Anaesth 1991;67(1):108-111.

3. Reves JG, Glass PSA, Lubarsky DA, McEvoy MD, Martinez-Ruiz R. Intravenous anesthetics. In Miller's Anesthesia, Miller RD (editor). 7th ed., Philadelphia: Churchill Livingstone/Elsevier, 2010:719768.

Address for Correspondence: Rümeysa Karaçuha Sürücü, Samsun Training and Research Hospital, Clinic of Anesthesiology and Reanimation,

E-mail: rksurucu@gmail.com ORCID ID: orcid.org/0000-0002-5031-5161 Received: 15.08.2021 Accepted: 11.10.2021

Cite this article as: Karaçuha Sürücü R. The Amount of Propofol Used Should be Specified in Milligrams Instead of Milliliters. Bagcilar Med Bull 2021;6(4):459

${ }^{\circ}$ Copyright 2021 by the Health Sciences University Turkey, Bagcilar Training and Research Hospital Bagcilar Medical Bulletin published by Galenos Publishing House. 